\title{
ЕКОНОМІЧНI НАУКИ
}

\author{
DOI: https://doi.org/10.32839/2304-5809/2019-11-75-96 \\ УДК 330.3 \\ Біла Ю.Ю. \\ Дніпровський національний університет імені Олеся Гончара
}

\section{ФОРМУВАННЯ КОНКУРЕНТНОЇ СТРАТЕГІЇ РОЗВИТКУ ПІДПРИЕМСТВА}

\begin{abstract}
Анотація. Досліджено теоретичні питання формування конкурентної стратегії розвитку підприемства. Сьогодні стратегічне управління для українського підприемства - це новий і незвичний підхід забезпечення його розвитку, адже без нього сучасне підприемство не зможе існувати на ринку тривалий час, тому стратегічне управління передбачае певні зміни та набирає сили. Для формування стратегії розвитку сучасного підприемства особливо важливим є виявлення та обгрунтування кола підприємницьких можливостей, їх структурування та виділення ефективних організаційних фрорм для забезпечення стабільного функціонування. Мова йде про ощінку потенціалу розвитку підприємства, коли всі елементи взаємопов'язані між собою, водночас це об'єктивно пов'язано з функціонуванням та розвитком підприємства та зовнішнього середовища.
\end{abstract}

Ключові слова: стратегічне управління, підхід до системного аналізу, навколишне середовище, показники, забезпечення, розвиток, підприемство, забезпечення конкурентоспроможності підприемств.

\section{Bila Yuliya \\ Oles Honchar Dniepr National University}

\section{FORMATION OF COMPETITIVE ENTERPRISE DEVELOPMENT STRATEGY}

Summary. Theoretical issues are investigated formation of competitive enterprise development strategy. Theoretical questions of forming of competition strategy of development of enterprise are investigational. Today a strategic management for the Ukrainian enterprise is new and unusual approach of providing of his development, in fact without him a modern enterprise will not be able to exist at the market long time, that is why a strategic management envisages certain changes and collects forces. For forming of strategy of development of modern enterprise especially important are an exposure and ground of circle of enterprise possibilities, their selection of effective organizational forms for providing of the stable functioning. Practically, the question is about the estimation of potential of development of enterprise, when all elements inter, at the same time it is objectively related to functioning and development of enterprise and environment. One of problems, any enterprises run into that, is a problem of safety of permanent development. The gradual revival of social responsibility, as to beginning of steady development, began. The gradual revival of social responsibility, as to beginning of steady development, began in the world in 70th past century. But, almost for half a century, radical changes in relation to embodiment in business of the real, veritable social responsibility and steady development of society, including labour collectives, it did not take place. Humanizing of society and him stable (life-giving lasting) development possible only at the terms of revival of ethic-moral culture of vital functions and menage our people, as it was in the days of our glorious of unheard of in the world of the Trypillia culture, "golden" age of development of Kyivska Rus. To qualificatory - the aim of enterprise is creation of harmonious relations between the members of labour collective on principles of all-round development of ethic-moral culture of vital functions, on that social, ecological and economic development of enterprise depends and him territorial association. By law basic - the constitution of Ukraine, basic value and source of welfare, is Man. For realization of this constitutional norm it follows to work out in Ukraine, legislatively to decree and realize socialresponsible politics of the state, including, passing to the classic (from lat. "primary, correct, exemplary") - socialoriented economy. The primary objective of vital functions of people and power, consumers and subjects of economic activity (senders of blessing) - all-round development of ethic-moral culture that envisages the equilibrium of necessities of vital functions of mass consumer and suggestion of enterprises must be observed.

Keywords: strategic management, approach to system analysis, environment, indicators, software, development, enterprise, ensuring the competitiveness of enterprises.

$\Pi$ остановка проблеми. За 28 років трансформації соціально-економічної системи України переважна більшість галузей господарювання залишалася збитковою, багато підприємств знаходиться у перманентній полісистемній кризі, а то й збанкрутували, що свідчить про нагальну необхідність докорінного оновлення системи управління суб’єктами господарської діяльності. Тобто, основною соціально-економічною проблемою на макро- та мікрорівнях залишається проблема забезпечення розвитку (оновлення) за кількісним та якісним вимірами. Перехід же до сталого (довговічного) розвитку підприемства у сучасних умовах господарювання практично не можливий. Потребується розробка і впровадження нової системи організаційно-управлінських новацій: призначення підприемницької діяль-

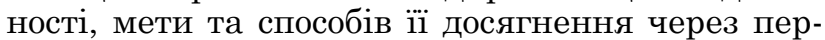
спективне довгострокове планування. Сьогодні стратегічне управління для українського підприємства - це новий і незвичний підхід забезпечення його розвитку, адже без нього сучасне підприємство не зможе існувати на ринку тривалий час, тому стратегічне управління передбачає певні зміни та набирає сили. Для форомування стратегії розвитку сучасного підприемства 
особливо важливим $є$ виявлення та обірунтування кола підприемницьких можливостей, їх структурування та виділення ефективних організаційних фрорм для забезпечення стабільного фрункціонування. Практично, мова йде про оцінку потенціалу розвитку підприємства, коли всі елементи взаємопов'язані між собою, водночас це об'єктивно пов'язано з функціонуванням і розвитком підприемства та зовнішнього середовища. Однією 3 проблем, з якою стикаються будьякі підприемства, є проблема безпеки постійного розвитку.

Чотири стратегічні альтернативи - обмежене зростання, зростання, скорочення та поєднання цих варіантів завжди є у розпорядженні керівництва підприємства. Підприемство обирає стратегію лише після аналізу зовнішніх можливостей і небезпек, внутрішніх сильних і слабких сторін та оцінки всіх альтернатив і варіантів, що $є$ класикою стратегічного управління, але в сучасних економічних і політичних умовах його може виявитися замало.

Аналіз останніх досліджень і публікацій. Тенденції розвитку та впливу науково-технічного прогресу на результативність підприемства свідчать про актуальність застосування стратегічного управління. «Будь-яка стратегія - це зміни, і будь-які зміни, спрямовані на вдосконалення будь-якого процесу, є інноваціями» [3]. На сьогоднішній день нововведення є запорукою успішного розвитку підприемства. Це визнає більшість вчених. Так, Коробейніков А., Трифілова А. [5] порівнюють інноваційне та стратегічне планування, відзначаючи різні аспекти їх взаємозв'язку. Вони вважають, що насправді завдання щодо розробки та усунення інноваційної продукщії та/або розробки нових технологій стоїть на чолі кожного стратегічного плану.

Зміни сучасної економіки тягнуть за собою зміни в системі стратегічного управління підприємством. Для того щоб стратегічний менеджмент набув нової форми і виступав як сучасний підхід до забезпечення розвитку підприємства, необхідно виявити деякі його показники, провести систематичний аналіз усіх середовищ, в яких працюе підприємство. Характеристикою цих показників є потенціал розвитку компанії, використання основних конкурентних переваг або балів для забезпечення зростання та правильного вибору основної чи конкурентної стратегії, ну і в кінці аналізу на макро / мікро ринку - умови, які систематично аналізують фактори обох середовищ.

Стратегія - сьогодні трактуе загальне управління. Дослідження вітчизняних та зарубіжних вчених значно розробили теорію стратегічного управління підприємством. Зокрема, різні проблемні питання формування стратегії розвитку суб'єктів, вплив науково-технічного прогресу на розвиток суб'єктів господарювання були описані такими відомими вченими, як: Ніжинська Н., Останькова Л., Фролов I., Геєць В., Кузьмін I., Сади А., Шваб Л., Федонін А., Войнаренко М.

Істотний внесок у розвиток теорії стратегічного управління 3 урахуванням змін фракторів зовнішнього середовища внесли іноземні вчені Гарет Б., Гібсон Дж., Го Сібао, Джейкобс Р., Каплан В., Кунц, Сі Чунтао та ін.
Виділення не вирішених раніше частин загальної проблеми. Дослідники стратегії розвитку підприемництва вважають, що найбільш важливою частиною роботи над формуванням підприємницької стратегії на середньостроковий та довгостроковий періоди є стратегія розвитку потенціалу підприемства. 3 цим можна погодитися, але лише частково. Також серед них ніхто не пропонує міркувань сучасного стійкого управління як саме основного підходу до розробки стратегії розвитку підприємства. Це також обумовлюе актуальність формування стійкого управління як сучасного підходу забезпечення розвитку підприємства на сьогоднішній день.

Метою роботи $є$ пошук та розробка теоретичних підходів до формування конкурентної стратегії підприємства, що досягається шляхом перетворення підприємства на конкурентоспроможний, складний, ефективний, високотехнологічний та сприйнятливий до інновацій суб'єкт господарювання, який динамічно розвивається та інтегруеться в систему розподілу праці. Тому визначення пріоритетів, механізмів та умов, які забезпечать прискорений, перспективний та стабільний розвиток українських підприемств, мають стати стратегічними завданнями на національному рівні. I головна мета реалізації стратегії - забезпечення технологічного рівня, що відповідає рівню підприємництва сучасних розвинених країн.

Виклад основного матеріалу. Стратегія як явище має суть і форму. Фактично, це комплекс взаємопов'язаних дій, які постійно коригуються i спрямовані на досягнення мети, поставленої учасниками процесу формування стратегії, одночасно забезпечуючи в довгостроковій перспективі ефрективне функціонування та розвиток підприемства. I за формою це узагальнена модель дій, необхідних для досягнення цих цілей. Цивільний кодекс України підкреслюе, що мета отримання прибутку е головним критеріем роботи будь-якого підприемства. Тому в цивільному законодавстві поняття "прибуток» застосовується як мета, яка дозволяє диференціювати підприємництво від інших видів діяльності учасників господарської діяльності.

«Сучасне стратегічне управління на підприемстві - це процес, зокрема, динамічного набору взаємопов'язаних елементів:

- визначення місії та цілей підприемства;

- аналіз внутрішнього та зовнішнього середовища підприемства;

- аналіз потенціалу розвитку підприемства;

- визначення етапу життєвого циклу підприемства;

- коригування місії та цілей;

- формування конкурентних переваг;

- визначення стратегічних альтернатив розвитку;

- вибір стратегії або декількох стратегій розвитку;

- визначення перспективних напрямків розвитку підприемства;

- розподілення ресурсів;

- реалізація стратегічних управлінських рішень;

- контроль результатів та оцінка ефрективності обраної стратегії розвитку» [6]. 
Формування стратегічного управління системою на підприемстві завжди грунтуеться, головним чином, на виборі певного варіанту стратегії 3 декількох альтернатив. Тому методи, що застосовуються при формуванні стратегії розвитку підприемства, найчастіше покладаються на сценарійний підхід, який базується на виборі сценарію стратегії розвитку підприемства 3 декількох, запропонованих за певним критерієм вибору. Крім того, використовуються методи типових рішень для поширених ситуацій. За класифікацією Котлера середовище підприємства підрозділяється на зовнішне та внутрішне. Зовнішне середовище поділяеться на макро- та мікросередовище. Прийняття довгострокових або оперативних рішень у бізнесі базується на кон'юнктурі ринку. Основна мета вивчення кон'юнктури ринку - визначення характеру та ступеня іï збалансованості, насамперед співвідношення попиту та пропозищіі. Аналіз можливих диспропорцій попиту та пропозиції попереджає про зміну ринкової ситуащії. У ринкових умовах головне - не економічне зростання, а якісне підвищення, яке розширюе можливості та сприйнятливість підприємств до інновацій та реагування на вплив факторів зовнішнього середовища.

Первинні ознаки розвитку підприемства можна виділити за двома групами. Це дозволяе розглядати координацію управління двома процесами: фріксований приріст потенціалу розвитку підприємств та ефрективне використання потенціалу як найважливішої продуктивної ознаки раціонального вибору стратегії розвитку підприємства.

Мова йде не про стратегію розвитку для конкурентного потенціалу підприемства, а про його частини або блоки стратегічного плану, як диференціацію стратегічної мети на місцеві цілі.

Розглянемо механізм управління процесами безперервного нарощування якісних та кількісних змін соціально-економічного потенціалу підприемства [1].

Знакові характеристики та сутність розвитку підприемства можна зазначити так:

1. Розвиток економічного потенціалу підприємства, який характеризує його конкурентоспроможність як процес розвитку якісних та кількісних змін:

- задоволення попиту інвестора або покупців продукції чи послуг, визначення собівартості та строку виконання замовлення, виконання певних договірних та контрактних зобов'язань;

- задоволення бажання організації забезпечити працездатність та їі розвиток у майбутньому;

- задоволення суспільних бажань (розвиток регіону чи галузі та зростання економіки України в цілому).

2. Управління потенційною економічною спроможністю підприемства, яка характеризуеться як процес управління постійним нарощуванням якісних та кількісних змін.

«На думку декількох дослідників, вибір стратегії певної організації як сучасний підхід забезпечення їі розвитку з метою підтримки фріксованого зростання стратегічного потенціалу стає вибором найбільш прийнятного варіанту» [2].

3 цих варіантів можна виділити два найважливіші:

1. Суть першого варіанту є постійне збільшення стратегічного потенціалу розвитку підпри- ємства та забезпечення можливості адаптації до зовнішнього середовища. Цей варіант зводиться до того, що такі компоненти, як організаційний, технологічний, інвестиційний, інноваційний та сощіальний, можуть входити до потенціалу стратегічного розвитку.

2. Суть другого варіанту - це повністю припинення зростання та підтримка стратегічного потенціалу розвитку підприемства, одночасно продовження забезпечення постійного припливу доходу за рахунок використання всіх існуючих ресурсів.

Тому аналіз точок зростання стратегії розвитку підприемства повинен спрямовуватися на посилення внутрішніх та зовнішніх точок зростання, таким чином, при паралельному зростанні динамічних можливостей та забезпеченні розвитку підприємства. «Коли розвиток дій, спрямованих на формування системи стратегічного управління, стає найважливішим завданням управління, внутрішні стратегічні резерви підприемства починають зростати».

Два етапи аналізу зовнішнього середовища підприемства (оцінка можливостей та визначення загроз) дозволяють оцінити стратегічні умови, створені зовнішнім середовищем.

Третій етап полягає у спільному дослідженні потенціалу та умов, коли їх робота надає значення стратегічній позиції підприемства. "Реальна сила цієї позиції буде визначена лише у випадку певного рівня стратегічної активності пращівників підприємства. Помноження стратегічної позищії на стратегічну діяльність дає стратегічну готовність, яку часто називають конкурентною перевагою» [9].

Основними елементами стратегії є пакет заходів, орієнтований на ефективну адаптацію до зовнішніх змін та використання основних конкурентних переваг або точок зростання, що належать підприемству:

1. Здатність адаптуватися до зовнішніх умов.

2. Необхідна величина потенціалу для стратегічного розвитку.

3. Саморегуляція, яка відповідає динаміці внутрішнього середовища.

Необхідна кількість потенщіалу інформує про наявність на підприемстві первинних можливостей для розвитку та зростання. «З набору можливих стратегій підприємство, як правило, вибирає лише одну, основну стратегію, яку називають конкурентоспроможною» [10].

Тепер розглянемо точку зростання - ресурси забезпечення розвитку:

1. Внутрішні точки зростання визначаються як ресурси, які підприемство використовуе для досягнення конкурентних переваг, і вони не копіюються:

- новітні, спеціальні технології, Hi-Tech;

- едрективні бізнес-процеси (складання бюджету, управління проектами, система розподілу);

- наявність висококваліфікованого персоналу.

2. Зовнішні точки - визначаються як ресурси, які надають підприемству істотні конкурентні переваги та дають можливість отримати зовнішню підтримку для забезпечення розвитку підприемства:

- постачальники недорогої сировини та запасів;

- можливість забезпечити необхідне фінансування (стосунки з інвестором, венчурними фондами та бізнес-ангелами); 
- успішне управління персоналом (університети, агентська праця, центри роботи);

- можливості лобіювання (спілкування з державними органами) [5].

Зупинимося на визначенні конкурентної стратегії забезпечення розвитку підприємства, характеристищі конкурентної переваги та відповідної стратегії:

1. Організаційні - низькі витрати на реалізацію; гнучкість; стратегія лідерства у витратах; стратегія розширення кордонів ринку.

2. Виробничо-технологічна - якість; дотримання строків угод; стратегія диференціації; наступальна стратегія; удосконалення продукту; інтенсифікація виробничого процесу.

3. Соціально-трудові - висока продуктивність праці.

4. Фінансово-економічні - «дешеві» фрінансові ресурси - стратегія вдосконалення діяльності; стратегія розвитку нових товарів.

5. Репродукційний потенціал - нові технології; удосконалення продукту; стратегія лідерства в продуктах.

6. Адаптивна - адаптація підприемства до впливів зовнішнього середовища; інтеграція ресурсів; інноваційний розвиток. Стратегія лідерства в інноваційних технологіях.

У сучасних економічних умовах зміна зовнішнього та внутрішнього середовища підприемства відбувається дуже швидко. Тому формування резерву гнучкості стає важливим, але інформація, необхідна для оцінки можливого впливу змін на процес формування стратегії розвитку підприемства, подається сумнівною через невизначеність ïх прояву та через усвідомлення. Існуе п'ять рівнів обізнаності, з яких п'ятий - найвищий. Цей рівень містить дуже великий обсяг інформації, яка дуже потрібна для здійснення стратегічного планування та подальшого розвитку підприємства [7]. Інформації, отриманої з цього рівня, зазвичай достатньо для розрахунку можливих негативних економічних результатів певних подій або позитивної послідовності подій як прорахунку результатів.
Розглядаючи перший рівень на відміну від п'ятого рівня, ми отримаємо мінімальну кількість корисної інформації, яку може отримати організація. Можна відзначити, що сьогодні в умовах фріксованої невизначеності багато підприемств перебувають на цьому рівні.

Реакція системи управління підприемством або його діями керівного персоналу в умовах різних силових сигналів є різною:

- в умовах сильних сигналів певна система зазвичай поділяеться на чотири групи: пасивність, контроль, стратегічне планування, своєчасне реагування відповідно до пріоритетних програм;

- в умовах слабких сигналів можливі поступові капітальні вкладення, прийняття рішень поетапно - в процесі покращення обізнаності підприемств [6].

У разі прийняття рішення щодо стратегічних питань, перш за все, необхідно встановити ступінь їхньої терміновості.

У 2013-2015 роках відродилася нова хвиля збитковості підприємств України. За цей період практично за всіма видами економічної діяльності, окрім сільськогосподарської, чистий прибуток суб'єктів господарювання залишався від'ємним. Середньо тривалий малий цикл склав 6 років, але сумарний збиток української економіки у 2014 р. у 14,2 рази перевищив від'ємний чистий прибуток у 2008 р. (-583785, 9 та $-41025,1$ млн. грн. відповідно, табл. 1). Розвиток соціально-економічної системи здебільшого перетворився на занепад.

Національні потреби у більшості випадків залишаються не задоволеними вітчизняними виробниками. Забруднюючи наше довкілля, продукція в основному направляеться за кордон. Британське видання «The Guardian» повідомило, що «Забруднення повітря в Україні викликало вчетверо більше смертей на душу населення, ніж у п’яти найчистіших країнах разом» [1].

Аналіз показує, що в умовах ринкової економіки зростання прибутків бізнес в основному забезпечуе через намагання перманентного підвищення цін на національному ринку, а

Таблиця 1

Формування чистого прибутку (збитку) великих та середніх підприемств України за видами економічної діяльності, млн. грн.

\begin{tabular}{|l|c|c|c|c|c|c|c|}
\hline \multirow{2}{*}{ Усього, у тому числі } & $\mathbf{2 0 0 8}$ & $\mathbf{2 0 0 9}$ & $\mathbf{2 0 1 0}$ & $\mathbf{2 0 1 1}$ & $\mathbf{2 0 1 2}$ & $\mathbf{2 0 1 3}$ & $\mathbf{2 0 1 4}$ \\
\cline { 2 - 8 } & $-41025,1$ & $-37131,1$ & 13906,1 & 67797,9 & 35067,3 & $-22839,7$ & $-258794,2(44,9)$ \\
\hline $\begin{array}{l}\text { сільське, лісове } \\
\text { господарство }\end{array}$ & 5789,2 & 7584,8 & 17170,5 & 25383,5 & 26787,2 & 14984,5 & $-982,6(12,1)$ \\
\hline промисловість & 5542,5 & $-14192,5$ & 11594,7 & 32229,9 & 2592,4 & $-4181,1$ & $-87731,6(6,6)$ \\
\hline будівництво & $-7975,4$ & $-4439,0$ & $-5095,7$ & $-2466,7$ & $-1012,7$ & $-5893,2$ & $-3702,7(47,5)$ \\
\hline торгівля & $-34093,2$ & $-13903,7$ & 7547,4 & 12046,7 & 210,6 & $-13248,5$ & $-46799,0(42,6)$ \\
\hline транспорт & 234,5 & 4889,5 & 1348,7 & 6500,0 & 3127,7 & $-1423,4$ & $-8037,5(48,6)$ \\
\hline \multirow{2}{*}{ Усього, у тому числі } & $\mathbf{2 0 1 4}$ & $\mathbf{2 0 1 5}$ & $\mathbf{2 0 1 6}$ & $\mathbf{2 0 1 7}$ & & & \\
\cline { 2 - 8 } & $-583785,9$ & $-373516,0$ & 29705,0 & 158849,8 & & & \\
\hline $\begin{array}{l}\text { сільське, лісове } \\
\text { господарство }\end{array}$ & 20325,9 & 102849,1 & 90613,2 & 382,9 & & & \\
\hline промисловість & $-174488,3$ & $-188267,9$ & $-24724,7$ & 72065,5 & & & \\
\hline будівництво & $-29067,4$ & $-25861,9$ & $-10553,0$ & 782,6 & & & \\
\hline торгівля & $-134356,5$ & $-88161,0$ & $-4841,8$ & 25599,6 & & & \\
\hline транспорт & $-26307,3$ & $-17847,8$ & 7408,7 & 5589,6 & & & \\
\hline
\end{tabular}

* за січень-вересень: у дужках - частка збиткових підприемств, \%

Джерело: розробка за "Держстат України" 1998-2017. http://www.ukrstat.gov.ua/ 
Таблиця 2

Індекси цін виробників промислової продукції (до відповідного періоду попереднього року)

\begin{tabular}{|c|c|c|c|c|c|c|}
\hline & 2012 & 2013 & 2014 & 2015 & 2016 & 2017* \\
\hline $\begin{array}{l}\text { Промисловість, } \\
\text { у тому числі }\end{array}$ & $\begin{array}{c}103,7 \\
(80,1-113,0)\end{array}$ & $\begin{array}{c}99,9 \\
(88,5-107,5) \\
\end{array}$ & $\begin{array}{c}117,1 \\
(105,0-137,7)\end{array}$ & $\begin{array}{c}136,0 \\
(108,7-156,9)\end{array}$ & $\begin{array}{c}120,5 \\
(97,8-156,3)\end{array}$ & $\begin{array}{c}127,5 \\
(106,1-163,1)\end{array}$ \\
\hline $\begin{array}{l}\text { добування нафрти та } \\
\text { природного газу }\end{array}$ & 112.8 & 107,5 & 111,2 & 211,7 & 156,3 & 134,5 \\
\hline $\begin{array}{l}\text { виробництво коксу та } \\
\text { продуктів нафтопереробки }\end{array}$ & 96,0 & 93,3 & 128,4 & 130,8 & 111,6 & 163,1 \\
\hline
\end{tabular}

* за січень-вересень.

Джерело: розробка за "Держстат України" 1998-2017. http://www.ukrstat.gov.ua/

здебільшого - за рахунок експорту, шукаючи все нові закордонні ринки збуту. Тенденція забезпечення максимізації прибутків за рахунок підвищення цін підтверджуеться таким прикладом: у 2013 році ціни на основні види промислової продукції знизилися (табл. 2) і негайно з'явився збиток у промисловості, відповідно і в національній економіці. Але наступне суттеве зростання цін у 2014-2015 рр., перш за все на енергоносії (відповідно індекси 111,2-211,7), викликало зворотній ефект - спричинило до падіння попиту на промислову продукцію особливо на національному ринку, що призвело до найбільших збитків як у промисловості (188,3 млрд. грн. у 2015 році), так і в національному господарстві (583,8 млрд. у 2014). У розумівши це, починаючи з 2016 року, бізнес змушений був піти на зниження цін, першочергово на енергоносії, що сприяло зменшенню збитків у цьому році та зростанню прибутків у 2017 році. Отже, життя корегуе всі наші стратегічні амбітні плани.

Аналіз господарської діяльності показуе, що тільки сільськогосподарська галузь ніколи не була збитковою, адже це пріоритетна галузь народного господарства, від розвитку якої залежить життедіяльність людини та успішне фрункціонування інших галузей з виробництва органічної, корисної для життедіяльності продукції. На сьогодні, коли більшість галузей збиткові, 90\% сільськогосподарських підприемств прибуткові, особливо в рослинництві, яке забезпечуе життедіяльність людей. Промисловість же, особливо важка, майже весь час збиткова, у тому числі, через велику шкоду, яку завдає людям від:

- непомірного «науково» технічного «прогресу» (розщеплення атому, безперервного удосконалення зброї, психотропна зброя, прояви генної інженерії, нано-технології, генно-модифрікована продукція: харчі, харчові добавки, лікарські препарати, вакцини, біорозмаїття: рослинний і тваринний світ та, навіть, спроба створити бездушну, фрактично мертву кібер-людину - робота);

- забруднення довкілля (радіаційне, електромагнітне, хімічне; відходами, сміттям);

- спокуси основною цінністю життя вважати егоїзм, жорстоку конкуренцію, неперервний кар'єрний ріст, пристрасть до грошей, матеріального збагачення, красивого (безтурботного, безглуздого) способу життя, що в кінці кінців може завершитися кризами та банкрутствами.

Усе це гіркий результат занепаду моральноетичної культури життедіяльності та господарювання людей.
Висновки і пропозиції. Зміни в сучасній економіці тягнуть за собою зміни в системі стратегічного управління підприемством. Однією з проблем, з якими стикається будь-який бізнес, $є$ питання забезпечення безперервності його розвитку та стійкості. У розпорядженні його управління завжди є чотири стратегічні альтернативи - обмежений ріст, зростання, скорочення та поєднання цих варіантів. Зараз стратегія обрана лише після аналізу зовнішніх можливостей та загроз, внутрішніх сильних та слабких сторін і оцінки всіх альтернатив та варіантів. Це класичне стратегічне управління, але в сучасних економічних та політичних умовах цього замало [14].

Актуальною сьогодні є сукупність стратегій, що враховує потенціал розвитку підприемства, мікро-макро-аналіз та кон'юнктуру ринку, що систематично впливає на фрактори обох середовищ.

Для того, щоб стратегічний менеджмент набув нової форми, і він виступав як сучасний підхід до забезпечення розвитку підприемства, необхідно виявити деякі його показники, провести систематичний аналіз усіх середовищ, де працюе підприемство.

Показниками сталого розвитку підприемств $\epsilon$ такі:

- економічні (рівень безкризовості бізнесу, коли власний капітал покривае отримані збитки, рівень беззбитковості бізнесу - наявність років збиткової чи беззбиткової діяльності);

- соціальні (випереджаючий ріст продуктивності пращі - виробітку по відношенню до росту заробітної платні; зростання питомої ваги зарплати робітників у собівартості продукції залежно від кількісного та якісного росту продукщї, рівня небезпеки й погіршених умов праці; ріст соціального капіталу - довіри співробітників підприемства до апарату управління, довіри споживачів, покупців та мешканців території до продукції (послуг) підприемства та його діяльності; удосконалення структури витрат 3 поступовою мінімізацією умовно постійних витрат до оптимального рівня $30 \%$; зростання рівня культурно-професійного навчання, підвищення кваліфрікації, наставництва - до постійно діючого; поступове впровадження безстрокового та довічного працевлаштування; покращення безпеки й умов праці; покращення культури господарювання тощо);

- екологічні (зростання обсягу екологічно чистої продукції; дотримання допустимих існуючих норм забруднення повітряного, водного й грунтового басейну та їх зменшення в перспективі). 


\section{Список літератури:}

1. Бурденюк Т.Г. Стратегічний аналіз критеріїв конкурентоспроможності підприемств. Проблели теорї та методології бухгалтерського обліку, контролю і аналізу : матеріали наук.-практ. конф. (12 квітня 2014 р.). Київ, 2014. С. 39-50.

2. Вагнер I. Роль стратегічного аналізу у виборі та розробці стратегії управління підприемством. Еконолічний аналіз : матеріали наук.-практ. конф. (23 травня 2010 р.). Львів, 2010. С. 98-104.

3. Держстат України 1998-2017. URL: http://www.ukrstat.gov.ua/ (дата звернення: 15.10.2019).

4. Новікова О.Ф. Діагностика стану та перспектив розвитку соціальної відповідальності в Україні (експертні оцінки) : монографія / О.Ф. Новікова, М.С. Дейч, О.В. Панькова та ін.; НАН України. Донецьк, 2013.296 с.

5. Кантаєва О.В. Проблеми інформаційного забезпечення інноваційної діяльності на вітчизняних підприемствах України. Вісник Університету банківської справи НБУ. 2012 . № 3. С. 130-134.

6. Куценко В.Й. Напрями розвитку соціально-оріентованої економіки України. Управління розвиткол суб’єтів підприєлниитва: механізли, реалї̈, перспективи : колект. монографія / за заг. ред. Т.В. Гринько. Дніпро, 2018. С. 220-229.

7. Куценко В.Й. Оцінка рівня розвитку соціальної відповідальності суб’екта господарювання : матеріали наук.практ. конф. I Innovative economy and problems of its formation in post-communist countries. Proceedings of Materials of International Scientific-Practical Conference Dedicated to the Foundation of the Institute. Tbilisi, 2016. P. 479-484.

8. Місько Г.А. Оцінювання економічної стратегії підприемств харчової промисловості. Київ, 2016. URL: http://www.liber.onu.edu.ua (дата звернення: 19.09.2019).

9. Порохня В.М., Безземельна Т.О., Кравченко Т.А. Стратегічне управління : навч. посібник. Київ : Центр навч. л-ри, 2012. 224 с.

10. Смольянинова Е.Н. Генезис форм і методів стратегічного управління: електронний науковий журнал. 2011. № 4. C. 35-40. URL: http://sisp.nkras.ru/issues/2011/4/smolyaninova.pdf (дата звернення: 01.07.2019).

11. Саух I.B. Передумови виникнення та особливості стратегічного менеджменту вітчизняних підприемств. Вісник ЖДТУ. Серія : Еконолічні науки. 2014. № 4. С. 179-186.

12. Шваб Л. Актуальність трудового потенціалу вітчизняних шдприемств в сучасних умовах господарювання. Вісник ЖДТУ. Серія : Еконолічні науки. 2011. № 2. С. 303-308.

13. Біла Ю.Ю. Перспективи розвитку стратегічного управління на вітчизняних підприемствах. Актуальні аспекти розвитку економічних процесів в Україні : зб. наук. праць студ. наук.-практ. конф. (Дніпро, 20 березня 2019 р.). Дніпро, 2019. Том 1. С. 19-23.

14. Біла Ю.Ю. Управління конкурентоспроможністю підприемства сфери послуг. Актуальні аспекти розвитку економічних процесів в Україні : зб. наук. праць студ. наук-практ. конф. (Дніпро, 20 березня 2019 р.). Дніпро, 2019. Том 2. С. 31-34.

\section{References:}

1. Burdeniuk, T.H. (2014). Stratehichnyi analiz kryteriiv konkurentospromozhnosti pidpryiemstv [Strategic analysis of enterprise competitiveness criteria]. Proceedings of the Problemy teorii ta metodolohii bukhhalterskoho obliku, kontroliu i analizu (Kiev, April 12, 2014). Kyiv, pp. 39-50.

2. Vahner, I. (2010). Rol stratehichnoho analizu u vybori ta rozrobtsi stratehii upravlinnia pidpryiemstvom [The role of strategic analysis in selection and development of enterprise management strategy]. Proceedings of the Ekonomichnyi analiz (Lviv, May 23, 2010). Lviv, pp. 98-104.

3. Derzhstat Ukrainy 1998-2017. URL: http://www.ukrstat.hov.ua/ (accessed: 15.10.2019).

4. Novikova, O.F. (2013). Diahnostyka stanu ta perspektyv rozvytku sotsialnoi vidpovidalnosti v Ukraini (ekspertni otsinky) [Diagnosing the status and prospects of social responsibility in Ukraine (expert assessments)]. Donetsk, 2013.

5. Kantaieva, O.V. (2012). Problemy informatsiinoho zabezpechennia innovatsiinoi diialnosti na vitchyznianykh pidpryiemstvakh Ukrainy [Problems of information support of innovation activity at domestic enterprises of Ukraine]. Bulletin of the NBU University of Banking, vol. 1, no. 3, pp. 130-134.

6. Kutsenko, V.Y. (2018). Napriamy rozvytku sotsialno-oriientovanoi ekonomiky Ukrainy [Directions of development of socially-oriented economy of Ukraine]. Upravlinnia rozvytkom subiektiv pidpryiemnytstva [Management of business entities: mechanisms, realities, perspectives]. Dnipro, pp. 220-229.

7. Kutsenko, V.Y. (2016). Otsinka rivnia rozvytku sotsialnoi vidpovidalnosti subiekta hospodariuvannia [Assessment of the level of social responsibility of economic entity]. Proceedings of Materials of International Scientific-Practical Conference Dedicated to the Foundation of the Institute. Tbilisi, pp. 479-484.

8. Misko, H.A. (2016). Otsiniuvannia ekonomichnoi stratehii pidpryiemstv kharchovoi promyslovosti [Evaluation of the economic strategy of food industry enterprises]. Kyiv. URL: http://www.liber.onu.edu.ua. (accessed: 19.09.2019).

9. Porokhnia, V.M., Bezzemelna, T.O., \& Kravchenko, T.A. (2012). Stratehichne upravlinnia [Strategic management]. Kyiv: Tsentr navch. l-ry, $224 \mathrm{p}$.

10. Smolianynova, E.N. (2011). Henezys form i metodiv stratehichnoho upravlinnia [Genesis of forms and methods of strategic management]. Elektronnyi naukovyi zhurnal, vol. 2, no. 4, pp. 35-40. URL: http://sisp.nkras.ru/ issues/2011/4/smolyaninova.pdf (accessed: 01.07.2019).

11. Saukh, I.V. (2014). Peredumovy vynyknennia ta osoblyvosti stratehichnoho menedzhmentu vitchyznianykh pidpryiemstv [Preconditions of the emergence and peculiarities of strategic management of domestic enterprises]. Visnyk ZhDTU. Seriia: Ekonomichni nauky, vol. 5, no. 4, pp. 179-186.

12. Shvab, L. (2011). Aktualnist trudovoho potentsialu vitchyznianykh shdpryiemstv v suchasnykh umovakh hospodariuvannia [Actual labor potential of the enterprises in the modern conditions of management]. Visnyk ZhDTU. Seriia: Ekonomichni nauky, vol. 7, no. 2, pp. 303-308.

13. Bila, Yu.Yu. (2019). Perspektyvy rozvytku stratehichnoho upravlinnia na vitchyznianykh pidpryiemstvakh [Prospects for the development of strategic management at domestic enterprises]. Proceedings of the Aktualni aspekty rozvytku ekonomichnykh protsesiv $v$ Ukraini [Actual aspects of economic processes development in Ukraine]. (Dnipro, March 20, 2019). Dnipro, T. 1, pp. 19-23.

14. Bila, Yu.Yu. (2019). Upravlinnia konkurentospromozhnistiu pidpryiemstva sfery posluh [Service Competitiveness Management]. Proceedings of the Aktualni aspekty rozvytku ekonomichnykh protsesiv $v$ Ukraini [Actual aspects of economic processes development in Ukraine]. (Dnipro, March 20, 2019). Dnipro, T. 1, pp. 31-34. 